\title{
Experimental study of the effect of limestone grading on some mechanical properties of concrete
}

\author{
Madiha Z. J. Ammari ${ }^{1, *}$ and Richard Fowler ${ }^{2}$ \\ ${ }^{1}$ Civil \& Infrastructure Engineering Department, American University of Ras Al Khaimah, Ras Al \\ Khaimah, U.A.E \\ ${ }^{2}$ Stevin Rock L.L.C, Ras Al Khaimah, U.A.E
}

\begin{abstract}
This study reports the experimental work undertaken to investigate the optimum grading of limestone to be used in concrete mixes. 36 concrete cubes were prepared for testing. Four different Fineness Moduli and grading were tested 2.4, 2.6, 2.92 and 3. For all tests, the cubes were left in curing until testing at the age of 3, 7 and 28 days respectively. Samples were loaded to failure and the average compressive strength was used for comparison purposes. Flow table test has been performed on the fresh concrete directly after mixing to measure workability and the average of the maximum concrete spread parallel to the two edges of the table was recorded. Results revealed that the optimum Fineness Modulus for the limestone to be used as fine aggregate in the concrete mix to get maximum compressive strength is 2.78 . The flow table tests revealed an increment in the workability of fresh concrete with higher Fineness Modulus of limestone used in the concrete mix as fine aggregate. The workability of the optimum Fineness Modulus, 2.78, was found to be $412 \mathrm{~mm}$ which is a mix with considerable workability. An ideal grading has been recommended in this research study and checked to match the ASTM grading requirements for fine aggregate.
\end{abstract}

\section{Introduction}

Concrete is the most commonly used material in construction industry all over the world. The conventional concrete is produced using natural sand from marine, river or dune as fine aggregate. Digging sand from river bed or marine in excess quantity is hazardous to environment. The cheapest and the easiest way of getting substitute for natural sand is obtained from manufactured sand from aggregate quarries known as limestone. Concrete made with limestone filler as replacement of natural sand in concrete was investigated by Omar M. Omar et al. [1] measuring its compressive strength, tensile strength, permeability and modulus of rupture. Concrete using various combinations of manufactured sand and quarry dust as complete or partial replacement for conventional river sand was investigated

\footnotetext{
* Corresponding author: madiha.ammari@aurak.ac.ae
} 
by a group of researchers such as Joseph O. Ukpata et al. [2], Rana Burhan Abdurrahman Alshahwany [3] and A. Jayaraman and V. Senthil kumar [4].

UAE is located in the middle of the gulf desert, and with the majority of its cities located close to the sea, there are two main possible sources of sand that can economically be used in the construction work, which are the desert or the sea. Desert sand is very fine which adversely affects the different properties of the produced concrete mixes in terms of compressive strength, workability and bond. On the other hand, the salt in the marine sand would affect the durability of reinforced concrete structures.

The sand in UAE is excavated from the bottom of the sea or ocean for different purposes including the excavation done for different offshore construction work. This sand is then transported to different local suppliers. The suppliers have the responsibility of washing the sand from salt and sieving to remove the large sized sea shells. Even though the marine sand, which is the source of sand used in UAE, is washed before distribution, it is not possible to get rid of all salts adhered to sand particles. Anyway, the marine sand is fine graded and cannot used lonely as fine aggregate in the concrete mixes.

Limestone, which is considered as aggregate quarry waste, could add the required properties to the concrete mix as fine aggregate in terms of compressive strength, workability, durability and sustainability. This study reports the experimental work undertaken to investigate the optimum grading of limestone to be used. The effects of limestone as fine aggregate on fresh and hardened properties of concrete had been investigated. The investigation included testing of compressive strength and workability of different concrete mixes.

While concrete made with limestone filler as replacement of natural sand in concrete was widely investigated for the best percentage of limestone to be used in the mix, no significant research work has been done to examine the effect of the Fineness Modulus and grading of limestone used as fine aggregate in concrete mixes and its effect on the different properties of concrete.

\section{Research methodology and data analysis}

\subsection{Materials used in experiments}

\subsubsection{Cement}

Ordinary Portland Cement (OPC) locally available in UAE was used in the experiment.

\subsubsection{Water}

Portable water available in the Civil and Infrastructure Engineering laboratory was used.

\subsubsection{Coarse aggregate (gravel)}

Crushed limestone from the quarry Stevin Rock L.L.C. located in Ras Al Khaimah was used in the experiment with specific gravity 2.59 , Bulk density $1480 \mathrm{~kg} / \mathrm{m} 3$ and grading shown in Fig (1). 


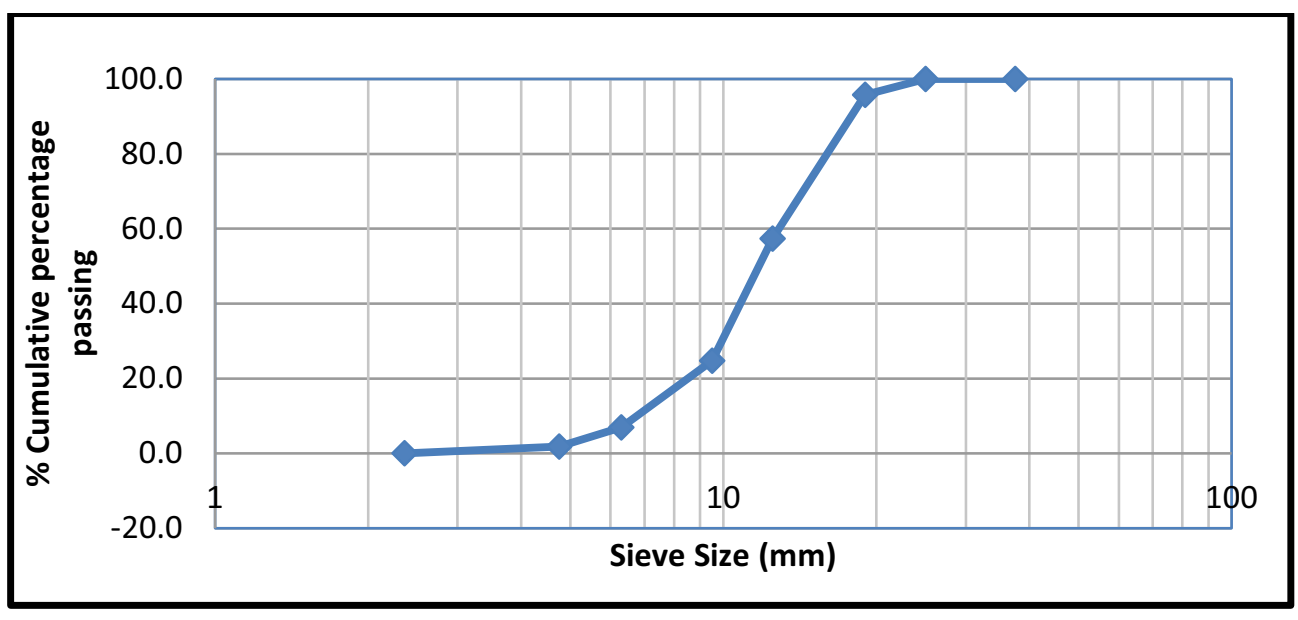

Fig. 1. Grading of coarse aggregate used in the experiments.

\subsubsection{Fine aggregate}

The fine aggregate used in the mixes was totally a limestone with different grading used in the different concrete mixes. The limestone used for testing all samples was provided by Stevin Rock L.L.C, which is the only aggregate quarry available in Ras Al Khaimah, one of the southern emirates of the United Arab Emirates. The limestone used for all mixes was dry and stored in the same place. The specific gravity of the limestone was found to be 2.8 .

Limestone with different Fineness modulus was used for each concrete mix. The required fineness modulus was achieved by sieving the limestone using automatic sieve shaker for a specified enough time to maintain the required quantity of retained limestone size on each standard sieve. Fineness modulus of 2.4, 2.6, 2.92 and 3 were prepared for the different concrete mixes. Tables (2) through (5) show the different grading of limestone used to achieve the different Fineness modulus used in each concrete mix. All used limestone grading matches the ASTM grading requirements of fine aggregate as mentioned in Neville and Brooks [5]. Table (1) below shows the ASTM standard grading requirements.

Table 1. ASTM requirements for grading of fine aggregate.

\begin{tabular}{|c|c|}
\hline Sieve size (mm) & $\begin{array}{c}\text { \% cumulative } \\
\text { Passing }\end{array}$ \\
\hline 10 & 100 \\
\hline 5 & $95-100$ \\
\hline 2.36 & $80-100$ \\
\hline 1.18 & $50-85$ \\
\hline 0.6 & $25-60$ \\
\hline 0.3 & $10-30$ \\
\hline 0.15 & $2-10$ \\
\hline
\end{tabular}




\subsection{Comparing the limestone grading used in the tests with ASTM requirements}

The grading of the limestone filler with different grading and fineness moduli 2.4, 2.6, 2.92 and 3 are all compared to the grading of fine aggregate required by ASTM. Tables (2) through (5) shows that all limestone grading used in the tests met the ASTM fine aggregate grading requirements.

Table 2. grading of limestone with fineness modulus 2.4.

\begin{tabular}{|c|c|c|c|c|c|}
\hline $\begin{array}{c}\text { Sieve size } \\
(\mathbf{m m})\end{array}$ & $\begin{array}{c}\text { Mass } \\
\text { retained (g) }\end{array}$ & $\begin{array}{c}\text { \% } \\
\text { retained }\end{array}$ & $\begin{array}{c}\text { \% } \\
\text { cumulative } \\
\text { Retained }\end{array}$ & $\begin{array}{c}\text { \% } \\
\text { cumulative } \\
\text { Passing }\end{array}$ & $\begin{array}{c}\text { ASTM \% } \\
\text { cumulative } \\
\text { Passing } \\
\text { required }\end{array}$ \\
\hline 10 & 0 & 0.0 & 0.0 & 100.0 & 100 \\
\hline 5 & 0 & 0.0 & 0.0 & 100.0 & $95-100$ \\
\hline 2.36 & 70 & 7.0 & 7.0 & 93.0 & $80-100$ \\
\hline 1.18 & 190 & 19.0 & 26.0 & 74.0 & $50-85$ \\
\hline 0.6 & 190 & 19.0 & 45.0 & 55.0 & $25-60$ \\
\hline 0.3 & 260 & 26.0 & 71.0 & 29.0 & $10-30$ \\
\hline 0.15 & 200 & 20.0 & 91.0 & 9.0 & $2-10$ \\
\hline 0.075 & 90 & 9.0 & & 0.0 & \\
\hline & & F.M & $\mathbf{2 . 4}$ & & \\
\hline
\end{tabular}

Table 3. grading of limestone with fineness modulus 2.6.

\begin{tabular}{|c|c|c|c|c|c|}
\hline $\begin{array}{c}\text { Sieve size } \\
(\mathbf{m m})\end{array}$ & $\begin{array}{c}\text { Mass } \\
\text { retained (g) }\end{array}$ & $\begin{array}{c}\text { \% } \\
\text { retained }\end{array}$ & $\begin{array}{c}\text { \% } \\
\text { cumulative } \\
\text { Retained }\end{array}$ & $\begin{array}{c}\text { \% } \\
\text { cumulative } \\
\text { Passing }\end{array}$ & $\begin{array}{c}\text { ASTM \% } \\
\text { cumulative } \\
\text { Passing } \\
\text { required }\end{array}$ \\
\hline 10 & 0 & 0.0 & 0.0 & 100.0 & 100 \\
\hline 5 & 0 & 0.0 & 0.0 & 100.0 & $95-100$ \\
\hline 2.36 & 35 & 3.8 & 3.8 & 96.2 & $80-100$ \\
\hline 1.18 & 235 & 25.6 & 29.4 & 70.6 & $50-85$ \\
\hline 0.6 & 260 & 28.3 & 57.7 & 42.3 & $25-60$ \\
\hline 0.3 & 186 & 20.3 & 78.0 & 22.0 & $10-30$ \\
\hline 0.15 & 121 & 13.2 & 91.2 & 8.8 & $2-10$ \\
\hline 0.075 & 81 & 8.8 & & 0.0 & \\
\hline & & F.M & $\mathbf{2 . 6}$ & & \\
\hline
\end{tabular}


Table 4. grading of limestone with fineness modulus 2.92 .

\begin{tabular}{|c|c|c|c|c|c|}
\hline $\begin{array}{c}\text { Sieve size } \\
(\mathbf{m m})\end{array}$ & $\begin{array}{c}\text { Mass } \\
\text { retained (g) }\end{array}$ & $\begin{array}{c}\text { \% } \\
\text { retained }\end{array}$ & $\begin{array}{c}\text { \% } \\
\text { cumulative } \\
\text { Retained }\end{array}$ & $\begin{array}{c}\text { \% } \\
\text { cumulative } \\
\text { Passing }\end{array}$ & $\begin{array}{c}\text { ASTM \% } \\
\text { cumulative } \\
\text { Passing } \\
\text { required }\end{array}$ \\
\hline 10 & 0 & 0.0 & 0.0 & 100.0 & 100 \\
\hline 5 & 0 & 0.0 & 0.0 & 100.0 & $95-100$ \\
\hline 2.36 & 76 & 8.1 & 8.1 & 91.9 & $80-100$ \\
\hline 1.18 & 337 & 35.8 & 43.8 & 56.2 & $50-85$ \\
\hline 0.6 & 225 & 23.9 & 67.7 & 32.3 & $25-60$ \\
\hline 0.3 & 130 & 13.8 & 81.5 & 18.5 & $10-30$ \\
\hline 0.15 & 87 & 9.2 & 90.8 & 9.2 & $2-10$ \\
\hline 0.075 & 87 & 9.2 & & 0.0 & \\
\hline & & F.M & $\mathbf{2 . 9 2}$ & & \\
\hline
\end{tabular}

Table 5. grading of limestone with fineness modulus 3 .

\begin{tabular}{|c|c|c|c|c|c|}
\hline $\begin{array}{c}\text { Sieve size } \\
\text { (mm) }\end{array}$ & $\begin{array}{c}\text { Mass } \\
\text { retained (g) }\end{array}$ & $\begin{array}{c}\text { \% } \\
\text { retained }\end{array}$ & $\begin{array}{c}\text { \% } \\
\text { cumulative } \\
\text { Retained }\end{array}$ & $\begin{array}{c}\text { \% } \\
\text { cumulative } \\
\text { Passing }\end{array}$ & $\begin{array}{c}\text { ASTM \% } \\
\text { cumulative } \\
\text { Passing } \\
\text { required }\end{array}$ \\
\hline 10 & 0 & 0.0 & 0.0 & 100.0 & 100 \\
\hline 5 & 0 & 0.0 & 0.0 & 100.0 & $95-100$ \\
\hline 2.36 & 120 & 12.0 & 12.0 & 88.0 & $80-100$ \\
\hline 1.18 & 337 & 33.7 & 45.7 & 54.3 & $50-85$ \\
\hline 0.6 & 225 & 22.5 & 68.2 & 31.8 & $25-60$ \\
\hline 0.3 & 144 & 14.4 & 82.6 & 17.4 & $10-30$ \\
\hline 0.15 & 87 & 8.7 & 91.3 & 8.7 & $2-10$ \\
\hline 0.075 & 87 & 8.7 & & 0.0 & \\
\hline & & F.M & $\mathbf{3 . 0}$ & & \\
\hline
\end{tabular}

\subsection{Fineness modulus (F.M) calculations}

The Fineness modulus (F.M) is calculated for each grading by finding the sum of the cumulative percentages retained on the sieves of the standard series, divided by 100.The standard series consists of sieves, each twice the size of the preceding one, $150 \mu \mathrm{m}, 300 \mu \mathrm{m}$, $600 \mu \mathrm{m}, 1.18 \mathrm{~mm}, 2.36 \mathrm{~mm}, 5 \mathrm{~mm}$ and $10 \mathrm{~mm}$. Higher value for Fineness Modulus indicates a coarser grading. 


\subsection{Mixes used in experiments}

A fixed concrete mix proportion with effective water cement ratio 0.64 was used for all mixes with cement-fine aggregate-coarse aggregate mix proportions of $1: 2.4: 1.8$ and the materials mixed thoroughly using pan mixer.

\subsection{Tests used in experiments}

\subsubsection{Flow table test}

Standard flow table, cone and tamping wooden rod were used in the whole tests in order to determine the workability of the fresh concrete mix. The inside of the cone and the table top were moistened at the beginning of each test. The cone is filled with concrete in two layers. Each layer is tamped 25 times with the standard tamping rod, and the top surface of the cone is surfaced by means of screeding. Immediately after filling, the cone is slowly lifted, and the unsupported concrete slumped. Before lifting the cone, excess concrete is removed, and surrounding table is cleaned. The table top then lifted and allowed to drop 15 times. The concrete spreads and the maximum spread parallel to the two edges of the table is measured. The average of these two values was recorded representing the flow of the fresh concrete mix in millimeters $(\mathrm{mm})$.

\subsubsection{Compressive strength of concrete}

Standard metal cubes $150 \mathrm{X} 150 \mathrm{X} 150 \mathrm{~mm}^{3}$ were used to cast concrete. For the purpose of testing the ideal grading and fineness modulus of limestone, 36 cubes were prepared for testing. Four different fineness moduli and grading were tested 2.4, 2.6, 2.92 and 3. For all tests, the cubes are left in curing until testing at the age of 3, 7 and 28 days respectively. For each curing time 3 samples were loaded to failure using MATEST compression testing machine and the average is recorded for comparison purposes. Table vibrator was used to c ompact all the samples for a specified tim e.

\section{Results and discussions}

The optimum Fineness Modulus and grading of limestone used as fine aggregate has been examined to improve the compressive strength and workability of concrete mixes. Table (6) and Figure (2) shows the average compressive strength for each Fineness Modulus of limestone used as fine aggregate to prepare standard specimens of the concrete mixes tested at the age of 3,7 and 28 days.

Table 6. average compressive strength (in MPa) of standard concrete cubes prepared using limestone with different Fineness Modulus as fine aggregate.

\begin{tabular}{|c|c|c|c|}
\hline F.M. of Limestone & 3 days & $\mathbf{7}$ days & 28 days \\
\hline $\mathbf{2 . 4}$ & 17.39 & 21.76 & 22.8 \\
\hline $\mathbf{2 . 6}$ & 22.89 & 24.37 & 31.09 \\
\hline $\mathbf{2 . 9 2}$ & 20.73 & 27.22 & 30.64 \\
\hline $\mathbf{3}$ & 18.15 & 20.87 & 26.24 \\
\hline
\end{tabular}




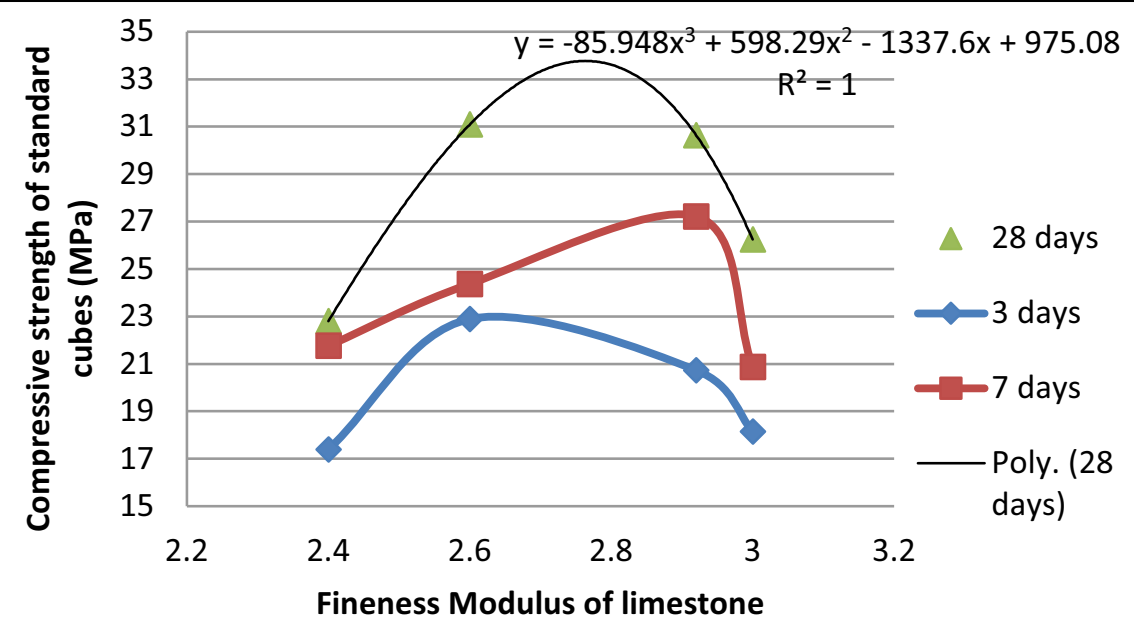

Fig. 2. Average compressive strength (in MPa) of standard concrete cubes prepared using limestone with different Fineness Modulus as fine aggregate.

As shown in Figure (2) a polynomial interpolation to the third degree is used for the 28 day testing results to determine the optimum Fineness Modulus for the limestone to be used as fine aggregate in the concrete mixes in order to improve the compressive strength of hardened concrete. To find the optimum Fineness Modulus of the lime stone, the derivative of the cubic equation is found and solved. See equation (1) below.

$$
\frac{d y}{d x}=-257.24 x^{2}+1196.58 x-1337.6=0
$$

Solving this derivation, the optimum fineness modulus for the limestone to be used as fine aggregate in the concrete mix to get maximum compressive strength is found to be 2.78 .

Table (7) and Figure (3) shows the average flow table test results for different Fineness Modulus of limestone used as fine aggregate to prepare the concrete mixes tested directly after mixing. The results reveal that there is an increment in the workability of fresh concrete with higher Fineness Modulus of limestone used in the concrete mix as fine aggregate. In other words, the workability of the fresh concrete mix increases with the coarser grading of the limestone. It is good to indicate that for the lowest Fineness Modulus of limestone, the standard cubes were honeycombed and the mix was obviously not workable which also leaded to lowest compressive strength recorded value.

Table 7. workability of fresh concrete mixes measured by the average record of the flow table test $(\mathrm{mm})$ for different Fineness Modulus of limestone used in the concrete mix.

\begin{tabular}{|c|c|}
\hline F.M. of Limestone & flow table (mm) \\
\hline 2.4 & 300 \\
\hline 2.6 & 388 \\
\hline 2.92 & 420 \\
\hline 3 & 425 \\
\hline
\end{tabular}




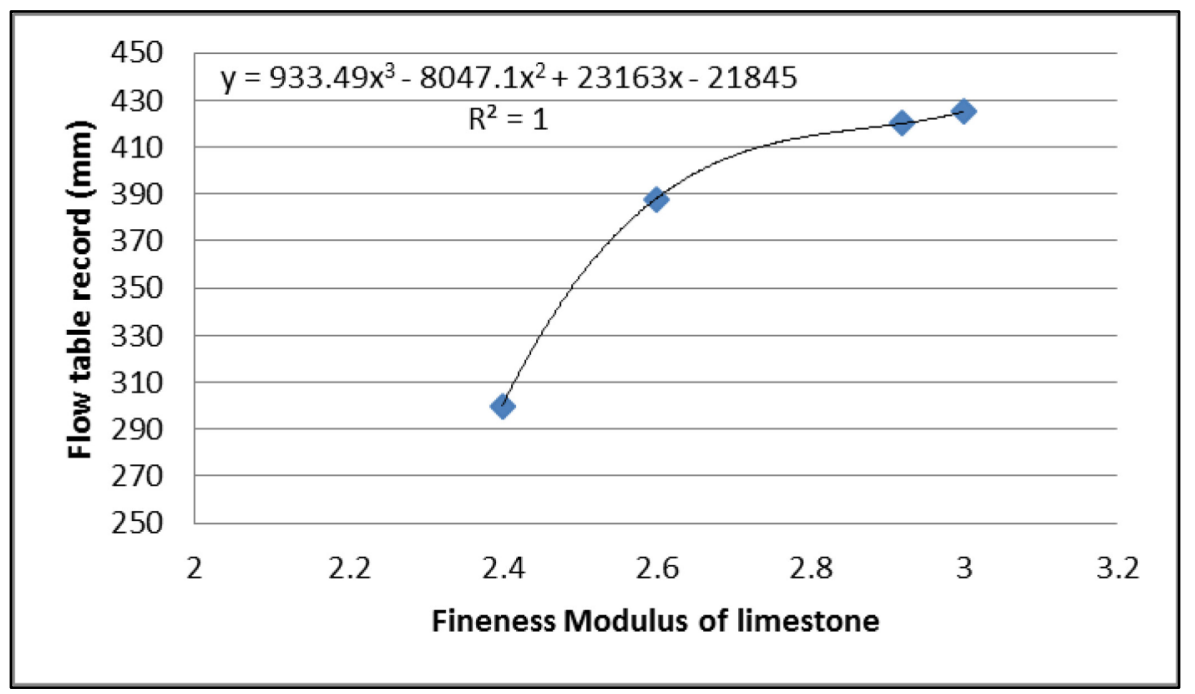

Fig. 3. workability of fresh concrete mixes measured by the average record of the flow table test $(\mathrm{mm})$ for different Fineness Modulus of limestone used in the concrete mix.

As shown in Figure (3) above, a polynomial interpolation to the third degree is used in order to determine the expected workability of the optimum Fineness Modulus for the limestone to be used as fine aggregate in the concrete mixes which is found previously as 2.78. Applying the Fineness Modulus value of 2.78 in the cubic equation, the expected flow table record would be $412 \mathrm{~mm}$ and this is a mix with considerable workability.

The recommended grading then can be found for the optimum Fineness Modulus for the limestone as shown in Table (8) below. Also, the recommended grading was checked and compared with the ASTM requirements for the fine aggregate in Table (8) below.

Table 8. Recommended grading of limestone with fineness modulus 2.78 .

\begin{tabular}{|c|c|c|c|c|c|}
\hline $\begin{array}{c}\text { Sieve size } \\
\text { (mm) }\end{array}$ & $\begin{array}{c}\text { Mass } \\
\text { retained (g) }\end{array}$ & $\begin{array}{c}\text { \% } \\
\text { retained }\end{array}$ & $\begin{array}{c}\text { cumulative } \\
\text { Retained }\end{array}$ & $\begin{array}{c}\text { \% } \\
\text { cumulative } \\
\text { Passing }\end{array}$ & $\begin{array}{l}\text { ASTM \% } \\
\text { cumulative } \\
\text { Passing } \\
\text { required }\end{array}$ \\
\hline 10 & 0 & 0.0 & 0.0 & 100.0 & 100 \\
\hline 5 & 0 & 0.0 & 0.0 & 100.0 & $95-100$ \\
\hline 2.36 & 57.7 & 6.2 & 6.2 & 93.8 & $80-100$ \\
\hline 1.18 & 295.9 & 31.6 & 37.8 & 62.2 & $50-85$ \\
\hline 0.6 & 243.2 & 26.0 & 63.8 & 36.2 & $25-60$ \\
\hline 0.3 & 145 & 15.5 & 79.3 & 20.7 & $10-30$ \\
\hline 0.15 & 109 & 11.6 & 90.9 & 9.1 & $2-10$ \\
\hline 0.075 & 85 & 9.1 & & 0.0 & \\
\hline & & F.M & $\mathbf{2 . 7 8}$ & & \\
\hline
\end{tabular}

\section{Conclusions}

The optimum Fineness Modulus of limestone to be used as fine aggregate in concrete mixes was found to be 2.78 and recommended grading was given in the research findings Table (8). 
The calculated workability for the recommended grading of limestone is found to be $412 \mathrm{~mm}$ which is considered as a workable mix. Any grading of fine aggregate should be checked and compared with the ASTM grading requirements. The recommended grading of limestone with the optimum Fineness Modulus of 2.78 met the ASTM grading of fine aggregate requirements as shown in Table (8) in the research findings above.

The findings of this research work is valuable for limestone manufactures, aggregate quarries, and suppliers in order to improve the different properties of the concrete mixes in terms of compressive strength and workability without extra cost by providing the limestone to the construction market with optimum Fineness Modulus and grading that meets the ASTM grading requirements for fine aggregates.

The authors would like to thank the School of Graduate Studies \& Research at the American University of Ras Al Khaimah for their financial support to this research work. The authors would also like to thank Stevin Rock L.L.C for providing this research with required coarse aggregate and lime, in addition to their support to the American University of Ras Al Khiamh with all equipment required to perform the tests.

\section{References}

1. Omar M. Omar, Ghada D. Abd Elhameed, Mohamed A. Sherif and Hassan A. Mohamadien, "Influence of limestone waste as partial replacement material for sand and marble powder in concrete properties". Housing and Building National Research Center (HBRC Journal), June 2012, Volume 8, pp 193-203 (2012)

2. Joseph O. Ukpata, Maurice E. Ephraim and Godwin A. Akeke, "Compressive strength of Concrete using Lateritic Sand and Quarry Dust as Fine Aggregate". ARPN Journal of Engineering and Applied Sciences, January 2012, Volume 7, No.1, pp 81-92. (2012)

3. Rana Burhan Abdurrahman Alshahway, "Effect of Partial Replacement of Sand with Limestone Filler on some properties of Normal Concrete".Al-Rafidain Engineering ,June 2011, Volume19, No.3 (2011)

4. A. Jayaraman and V. Senthil kumar, "Optimization of fully replacement of natural sand by $m$-sand in high performance concrete with nanosilica". International Journal of Emerging Technology and Advanced Engineering, November 2013, Volume 03, Issue 11, pp 497-502 (2013)

5. A.M. Neville and J.J. Brooks, "Concrete Technology", Prentice Hall, (2010) 